\title{
Importance of Girls' Education as Right: $A$ Legal Study from Islamic Approach
}

\author{
Mohammad Saiful Islam \\ Department of Law, International Islamic University Chittagong, Chittagong, Bangladesh \\ Email: lawsaiful@gmail.com
}

Received 16 November 2015; accepted 2 January 2016; published 5 January 2016

Copyright (C 2016 by author and Scientific Research Publishing Inc.

This work is licensed under the Creative Commons Attribution International License (CC BY). http://creativecommons.org/licenses/by/4.0/

(c) (i) Open Access

\begin{abstract}
Knowledge gaining and application is a fundamental necessity for all Muslims to qualify them to believe according to the ideologies of the religion. Islam ordered acquisition and dissemination of knowledge is obligatory (fard) upon its believers, irrespective of gender. The aim of education in Islam is to produce a decent human being who is talented of delivering his duties as a servant of Allah and His vicegerent (khalifah) on earth. This paper is an effort to examine the concept, goal and objectives of education on the view point of Islam. The aim of this article is to present and analyze the exact views of Islam regarding girls' education from the ultimate source of Islam. These works also try to pick out the common barriers of girls' education in Bangladesh.
\end{abstract}

\section{Keywords}

Education, Al Quran, Knowledge, Girls' Education

\section{Introduction}

Historically women have been subjected to social injustice and educational dispossession. Before advent of Islam Arabs has engaged to infanticide the girls' babies and Islam frequently recognize the dignity and rights of girls. Education is the prime human rights of human being after ensuring the right to life. Hence Allah firstly instructs the prophet to read and acquire knowledge as a divine guide. Islamic Education is one of the greatest schemes of education, which makes a decent presented person with all the potentials. In Islam, pursue knowledge is a holy duty. The significance of acquirement and broadcasting education has been highlighted constantly in the Qur'an and hadith, which are the decisive source of direction for Muslims. The Prophet (s.m) said, "Convey from me even an Ayah of the Qur'an.” (Al-Bukhari, 1987). Girls or women are total half of population of every society; avoiding or treating them as less importance does not survive in the Muslim society. Unfortunately by the weakness of Muslim with adverse and fallacious propaganda of opposition against Islam, accurate position of 
Islam towards girls' education is absent-minded. The specific objectives are from this study to recognize the Islamic approaches towards girls' education from the view point of Quran and hadith, to broadcast the genuine attitude of Islam about obtaining knowledge out of gender discrimination, and to explore the major barriers of girls' education in Bangladesh. Nik \& Yaacob (2013) discussed about concept of education in Islam and Yasin et al. (2013) argued aim and objectives of education in Islam. Rayan (2012) mentions Islamic education from philosophical aspect. Abukari (2014) shows education of women from Quranic perspective. Al-Naquib Al-Attas (1979) and Al-Attas (1980) discussed on concept, aim and objectives of education in Islam.

\section{Concept of Education from Islamic Perspective}

The word Education has been derived from Latin word: “educare, educere, educatum, educates” or "education” which indicates to lead pupils or pull out there dormant abilities (Alamgeer, 2010). The word "educare” means "to bring out” or "to nourish" where "educere” means "to lead out” or "to draw out”, “educatum” means "act of teaching” or "training”, “educates” means “to bring up, rear, educate” and “education” means “a breeding, a bringing up, a rearing” (Parankimalil, 2012). The Greek word “pedagogy” is also sometimes used for education (Parankimalil, 2012). Several scholars have attempted to define Education from their own approaches. According to Aristotle, "Education is a process necessary for the creation of sound mind in the sound body". According to Socrates, "Education is the mean that helps in searching the truth” (Imaillah, 1999). Imam Ghazali defines, "Education is a process which enables an individual to distinguish between the true and the false, the good and bad and the right conduct and the evil doing.” (Asif \& Khan, 2010).

The concept of education in Islam from the terminological and philosophical point of view, Al-Attas states, "Recognition and acknowledgement, progressively instilled into man, of the proper places of things in the order of creation, such that it leads to the recognition and acknowledgement of the proper place of God in the order of being and existence.” (Al-Attas, 1980). Education in Islam is “an education which trains the sensibility of an individual, in such a manner that their attitude towards life, their actions, decisions and approach to all kinds of knowledge are governed by the spiritual and deeply felt ethical values of Islam” (Ashraf \& Hussain, 1979). It is a mode of training the body, mind and soul through informing the knowledge of all kinds i.e. fundamental as obligatory and specific as optional (WORLD-COME, 1977). It formulates human beings for complete life with no separation of this short-term life which ends with death, and the eternal life that begins after death (Sarwar, 2001). Education in Islam is not simply of obtaining intelligent knowledge but it is a process of decoration the nature and character of an individual so that they can jointly represent Islamic ethics, work as khalīfatullāhfi al-ard (vicegerent of Allāh on the earth) (Ashraf \& Hussain, 1979), watcher of true, nobility and human greatness (WORLD-COME, 1977). In other word, education is "a method through which human beings are competent and organized in a concerted way to do their Creator's command in this life (dunyā) to be pleased in the life of hereafter (äkhirah).” (WORLD-COME, 1977).

According to Al-Attas, the meaning of education is inherent in the associations of term "tarbiyyah", "ta'lim”, and "ta'dib” taken altogether. Though all terms denote to education, ta'dib is more perfect and exact in understanding the concept of education (Daud, 1998). Ta'lìm, from the root “alima” means to instruct, to teach, to train, to school, and to educate, which contains elements of knowledge through teaching and learning. Tarbiyah, from the root "raba" means to nurture, to bear, to feed, to foster, to nourish, to cause to increase growth, to rear, and to bring forth to mature produce, which denotes the method of education that gives stress on physical, intellectual, spiritual and ethical development of an individual in accordance with the will of Allah (Al-Attas, 1991). However, tarbiyyah is not suitable to carry the meaning of education from its terminological point of view. Because this meaning is not only applicable to human, but also to other species such as animal and plants (Al-Attas, 1991). Ta'dīb, from the root “addaba” denotes to be cultured, refined, to discipline (Wehr \& Cowan, 1979), well-mannered, implies the process of education that delivers emphasis on nurturing worthy human beings with decent codes of conduct accepted by Islam, so that he displays behavior and position himself in the society with fairness and justice (Khamis \& Salleh, 2010).

The concept of education in Islam must takings into reflection of all the dimensions specified above (Yasin, et al., 2013). The word ta'dib is also used by the prophet (s.m) when he says, "My Lord educated (addaba) me, and made my education (ta'dib) most excellent.” (Al-Ghazali, 1993). Adab includes disciplining the mind and soul. It is also about achievement of good abilities and qualities of the mind and soul, so that individual can distinguish between: good and bad; right and wrong; and real and false (Al-Naquib Al-Attas, 1979). Three elements inherent in the concept of education i.e., the method, a content, and recipient refer to "human beings" (Al-Attas, 
1991). The comprehensively recognized meaning of education today is growth and development. It is a continuous and lifelong process of one's potentialities (Khan, 1988). This opinion is repeated in the Hadith-The Prophet said, "Acquiring knowledge from the cradle to the grave.” In conclusion, in the context of Islam Education is the organized process of acquiring knowledge that makes a complete person, including the rational, spiritual, and social dimensions.

\section{The Views of Quran on Knowledge Acquisition}

BeThe Qur'an places the utmost emphasis on the importance of the acquisition of knowledge. Al Quran states: "Are those equal, those who know and those who do not know? It is those who are endued with understanding that receive admonition.” (Quran 39: 9, Ali, 1989a). It is understood from this verse that the rank of the learned and their honor are much high (Al-Ghazali, 1993). It drives further to encourage believers to pray for improvement in knowledge and stresses on knowledge achievement even in times of crisis. In Islam all knowledge is reflected religious be it rooted in the social, physical sciences, professional or theological field. This is confirmed in several verses that command, advice, encourage and warn, people to detect the phenomenon of nature, to look into all in the universe, to travel, examine, explore, and understand them (Abukari, 2014).

Placing Islamic education in the context of knowledge acquisition should be able to draw out the potential good in the individual, to substitute error with truth, to transfer from illiteracy and incompetence to knowledge and competence. The Quran says: "By the Soul, and the proportion and order given to it. And its enlightenment as to its wrong and its right-Truly he succeeds that purifies it, and he fails that corrupts it.” (Quran 91: 7-10). The Qur'an discourage the only memorization of heavenly revelation without practice its order and such education is empty of meaning in respect of use to the individual and society in this life and the hereafter as well. In this favor the Qur'an says: "The similitude of those who were charged with the (obligations of the) Mosaic Law, but who subsequently failed in those (obligations), is that of a donkey which carries huge tomes (but understand them not).”(Quran 62: 5).

\section{Standards for Islamic Education}

Numerous Islamic scholars in the arena of education contribute effort to state the standards of Islamic education, i.e. Muhib Aldin, Abu al Rahman, Dr. Saied and Dr. Mugdad Yalgin are the debaters. Muhib Aldin explains Islamic education contain the raising and development of an individual life by the color of Islamic model together with bodily, mentally and intellectually. Abu Salih exactly shows Islamic Education considered the nurturing and preparation of the Muslim for his worldly and eternal life. The content and systems of education will closely destined by the philosophy and ideology of Islam (Abu Salih, 1982). Dr. Saied considered Islamic Education as the organized ideas and thoughts which are structured in intellectual outline itself built on an Islamic philosophical and moral framework (Abu Salih et al., 1982). Abd al Rahman Al Nahlawi detects Islamic education as a set of practical and oral actions motivated by knowledge of the Qureân and Sunnah and founded on them in matters to do with faith (Abu Salih et al., 1982). Dr. MugdadYalgin cited Islamic education as an autonomous educational system containing its separate basic aspects, purposes and methods; all motivated by the major philosophical principals of Islam (Yalgin, 1986). The basic criteria of Islamic education are which creates human resources ensuing the Islamic teaching; particularly spirituality and morality. It is the process for an individual to achieve divine code. Islamic education arrangements many subjects, i.e. Islamic theology, Science, philosophy, sociology, geography, Islamic culture and civilization.

\section{The Goal of Education in Islam}

Allah declares in the Holy Quran, "Nor should the Believers all go forth together: if a contingent from every expedition remained behind, they could devote themselves to studies in religion, and admonish the people when they return to them, -that thus they (may learn) to guard themselves (against evil).” (Quran 9: 122). Al-Qurtobi, the renowned Quranic scholar, stated the above verse of the Holy Quran indicates the goal of Islamic education. The goal of that education described as understanding in religious matters (tafaqquhfi al-dinn). Knowledge seekers are delegated with the obligation to circulate the knowledge and skills they knew to those who do not have the chance to acquire knowledge (Yasin, Firdaus, \& Jani, 2013). The aim of Islamic education is not to fill up the learner's head with particulars but to formulate them for a life of pureness and seriousness. This total pledge will build based on the models of Islamic ethics is the maximum goal of Islamic education (Al-Naquib Al-Attas, 1979). 
Al-Attas further mention "the comprehensive and unified approach to education in Islam is focused toward the "balanced development of the total personality...through training Man's spirit, intellect, rational self, feelings and bodily senses...such that faith is infused into the whole of his personality.” (Al-Naquib Al-Attas, 1979).

In Islam the purpose of education is to enlighten the human soul and improves the resources of knowledge that helps in knowing Allah SWT, the Creator of all humankind and universe. This will promote the sense of obligation to worship the Creator and obey His command at all periods and circumstances. The Quran says, “And I did not create the jinn and mankind except to worship Me.” (Quran 51: 56). Al-Ghazālī narrates the aim of education with the purpose of life that is to achieve pleasure by getting close to God. Therefore, the aim of education is "to improve in man a personality that abides by the educations of religion, and is hence assured of salvation and happiness in the eternal life of the Hereafter." (Nofal, 1993) Muslim students have to be aware that the acquisition of knowledge is "not merely to satisfy an intellectual curiosity or just for material or worldly gains, but to produce rational and righteous human beings, who are able to meet the spiritual, moral and physical needs of their families, their people and mankind” (Ashraf \& Hussain, 1979). A perfect personality like this is a product of education whose philosophy is founded on faith in Allah and a promise to realize God-given moral code well-entrenched in the sacred teaching of Sharīah (Ajijola, 1999).

The aim of education in Islam as specified in the First World Conference on Muslim Education held in JeddaMecca (1393A.H.-1977A.D.) "Education should aim at the balanced growth of the total personality of man through the training of man's sprit, intellect, his rational self, feelings and bodily senses. Education should cater therefore for the growth of man in all aspects: spiritual, intellectual, imaginative, physical, scientific, linguistic, both individually and collectively and motivate all aspects towards goodness and the attainment of perfection. The ultimate aim of Muslim education lies in the realization of complete submission to Allah on the level of the individual, the community and humanity at large." (Ashraf, 1985)

The ultimate goal of Islamic education is certainty that knowledge without the origin in faith and religion is merely partial education. Islamic education teaches the promise towards the basic values which have been arranged in religion and scripture. It also emphases on the sense of accountability towards Almighty Allah so that men can pass their lives as a faithful servant (Sharif, 1964). International brotherhoods can be succeeded by the teachings from Islamic education irrespective of differences in groups, occupations and social classes amongst the persons who are knit together by a common religion and faith. The aim of Islamic education is that people be capable to live as he lived. While education does make humankind for happiness in this life, "its ultimate goal is the abode of permanence and all education points to the permanent world of eternity.” (Nasr, 1984).

\section{Islamic Views on Girls' Education as Rights}

\subsection{The Principal Identity of Human Being}

Islam is the only single religion which first direction of the Holy Scripture was revealed with the direction of education. Allah says in the Quran, "Read! In the Name of your Lord who has created (all that exists). He has created man from a clot (a piece of thick coagulated blood). Read! And your Lord is the Most Generous. Who has taught (the writing) by the pen. He has taught man that which he knew not.” (Quran 96:1-5) The first word in Arabic "Iqra" is a command that means "read" and that includes the ideas of "learning”, "exploring” and "seeking education". Education is the initial point of each human activity. Education is the main uniqueness of human being all over the creation. Allah honored human being over all of His creations for the knowledge and wisdom. The first human being (Adam) in the world was recognized greatest by his knowledge to all creatures. The angels and Satan failed in the test of knowledge. Hence the vicegerency was assigned to Adam. Al Quran says, "And He taught Adam the names of all things; then He placed them before the angels, and said: "Tell me the names of these if ye are right.” (Quran 2: 31) Al Quran further declares, “..Allah will rise up, to (suitable) ranks (and degrees), those of you who believe and who have been granted (mystic) Knowledge. And Allah is wellacquainted with all ye do.” (Quran 58:11) Moreover, Allah sent many messenger including the last prophet Muhammad in several eras with knowledge and wisdom in the world for presentation correct path to those who were afield from Islam. Allah says, "And to Lut, too, we gave Judgment and Knowledge, and We saved him from the town which practiced abominations: truly they were a people given to Evil, a rebellious people.” (Quran 21:74) It is particularly mention that Allah honored His apostle Muhammad with the knowledge, wisdom which; He taught it to Muhammad so that he might teach it to mankind. The Holy Quran says, “Allah did confer a great favor on the believers when He sent among them a messenger from among themselves, rehearsing unto them the Signs of Allah, sanctifying them, and instructing them in Scripture and Wisdom, while, before that, 
they had been in manifest error.” (Quran 3:164) Most of the Prophet hunted to Allah for increasing their knowledge, i.e. Hazrat Ibrahim (A.) said- "O my Lord! Bestow wisdom (Hukm) on me, and join me with the righteous.” (Quran 26: 83) Allah also taught teaching for increasing knowledge. Al Quran says, "O my Lord! Increase me in knowledge.” (Quran 20: 114).

\subsection{Fulfillment of Purpose for Creating Humans}

Islam has faith in that the source of human beings is Allah and the final arrival will be to Allah. It also believes that human beings must be submissive to Allah as the creator. In Islam the purpose of the creation of human is specified undoubtedly in the Quran. Allah says in the Quran: "I have created jinns and men, that they may serve Me. No sustenance do I require of them, nor do I require that they should feed Me. For Allah is He who gives (all) sustenance.” (Quran 51: 56-58). He also says: "And make not another object of worship with Allah.” (Qur'an 51:51) Since the above verses, Islam establishes that the objective of the creation of the human kind is not share Allah with anything in the form of food, shelter or anything necessary for nourishment but to worship Him (Abukari, 2014).

In Islam worship is not only the formalized activities but includes righteousness and a comprehensive submission to the will of Allah in all attempt, that is, exploit what He has ordered (good actions) and eluding what He dislikes of (evil). The Quran says: "It is not righteousness that ye turn your faces towards East or West; but it is righteousness-to believe in Allah and the Last Day, and the Angels, and the Book, and the Messenger; to spend of your sustenance, out of love for Him, for your kin, for orphans, for the needy, for the wayfarer, for those who ask, and for the ransom of slaves; to be steadfast in prayer; and practice regular charity, to fulfill the contracts which ye have made; and to be firm and patient, in pain (or suffering) and adversity, and throughout all periods of panic. Such are the people of truth, the God-fearing.” (Quran 2: 177) This verse indicates simply prayers or ceremonial deeds are not worship but the belief in Allah and perform actions by supported Him. The Quran further says: “To the Madyan people We sent Shu'ayb he said: “O my people worship Allah Give just measure and weight, nor withhold from the people the things that are their due; and do no mischief on the earth after it has been set in order" (Quran 7: 85) The space of worship also covers giving just weight and measure particularly in commercial transactions; avoid suppression from people the things that are their due, and all roguish acts. From the above argument, it indicates that the purpose of creating human beings is to worship Allah, and the worship of Allah contains doing what Allah commands and evading all that He prohibits. So, each Muslim (man and woman) desires to have knowledge of what Allah enjoys and hates in order to worship Him. In fact, no one can successfully worship Allah when one does not identify how to worship. Girls are human beings generated by Allah with a central objective to worship Him. Therefore, they have the equal rights to obtain knowledge in order to accomplish their purpose of being created (Abukari, 2014).

\subsection{Good Vicegerent of Allah on the Earth}

Allah creates human being as a vicegerent on the earth for establishing His rules and give specific guidelines for to be good vicegerent as per direction of Allah which purely possible through acquiring knowledge. Al-Attas constantly highlights that the purpose of education in Islam is not simply to produce a noble citizen or a good worker, but more than that, a good vicegerent of Allah (Al-Attas, 1978). Al-Attas further says that a good citizen in a secular state may not essentially be a good man; a good man, however, will absolutely be a good citizen. As a result, a man who is good in the common society must be virtuous and just to himself first (Al-Naquib Al-Attas, 1979). Islam admits the idea of good citizenship as the object of education. The principal attention on the individual is so essential because the final purpose and end of ethics in Islam is the individual. "It is because of this notion of individual accountability as a moral agent that in Islam it is the individual that shall be rewarded or punished on the Day of Judgment.” (Wan Daud, 2010). Those who have knowledge are obedient to Allah (righteous) because they obtain knowledge of the doing and avoiding and explore in their daily living. Being the noble vicegerent of Allah, man is educated about how to accomplish his religious and sociopolitical dealings on earth as means to understand the purpose of his creation in accordance with the complete will the Creator.

\subsection{Discharge Religious Duties}

Al-Ghazālī considered obtaining religious sciences is mandatory for every Muslim because it is necessary for the discharge of an individual's Islamic duties (Khan, 1981). Ibn Sina considered used the terminology of 
ta'dībto denote education. For duly practice the duties of Islam He emphasized that the method of education begins as soon as the baby completed his two years breastfeeding age (Ibn Sina, 1929). According to Islam, seeking out knowledge is essential to bright the human soul and improves the room of knowledge that helps in identify Allah, the Creator of all humankind and cosmos and make the sense of responsibility to worship the Creator and obey His command at all spells and positions. In respect of smooth perform of religious duties the Qur'an itself has provided a vital guide to help Muslims to realize and apply its principles is the concept of following the greatest meaning in it. In this connection, the Qur'an says: "Those who listen to the Word, and follow the best (meaning) in it: Those are the ones whom Allah has guided, and those are the ones endued with understanding." (Qur'an 39: 18) If the term "word" in the verse is understood as the Word of Allah or the memorandum of the Qur'an, it indicates we need to understand and apply the message in the best mode (Abukari, 2014).

The ultimate purpose of the creation of mankind as specified in the Quran, that is, to worship Allah. Al Quran announces "And I did not create the jinn and mankind except to worship Me.” (Quran 51: 56). Therefore, for performance of worship of Allah and discharge of religious duties learning and teaching is necessary for girl. The parents or guardians must be teach the girl all rules, correct way of worshipping and modes of worshipping (Islam, 2015). Allah says: "And (remember) when Luqmaan said to his son: "O my son, do not associate with Allah. Indeed, association others with Allah is a great Zulm (injustice).” (Quran 31: 13). The Messenger of Allah said: "Teach the child to pray when he is seven years old, and smack him (lightly) if he does not pray when he is ten.” (Al-Sijistani \& Hasan, 1993). Education about religion or worship must directed early phases of childhood when mind of child is completely free from all kinds of debauched things (Islam, 2015).

\subsection{Education for All Irrespective of Discrimination}

Allah has created human being with indefinite talents and merits and has instructed for developing these talents through seeking education (Badshah, 2012). Islamic education strategy and practice have provided equal opportunities for both men and women (Abukari, 2014). Acquirement of knowledge ('ilm) is stressed in Islam as a significant action besides its dissemination. It has been made obligatory ( fard) upon its believers, irrespective of gender, to learn and broadcast knowledge (Yasin et al., 2013). The responsibility of seeking out knowledge is binding upon every Muslim by the command of the Qur'an and Sunnah of the Prophet (s.m). Allah says: “Are those equal, those who know and those who do not know? It is those who are endued with understanding that receive admonition.” (Quran 39: 9) The Prophet (s.m) said, "Acquire knowledge and impart it to the people.” (Tirmizi, 1980) hadith, 107 He also said, "Seeking knowledge is compulsory for every Muslim.” (Al-Bukhari, 1987, Hadith, 9). The study of the life of the Holy Prophet (s.m) also shows that he himself made special measures for the education and teaching of girl and women. Abu Sa'id al-Khudri reports that some women said to the Holy Prophet (s.m): "men have gone ahead of us (in terms of acquisition of knowledge). Therefore, appoint a special day for our benefit as well.” The Holy Prophet (s.m) fixed one day for them. He would meet them on that day, advise them and educate them about commandments of Allah Almighty (Al-Bukhari, 1987).

In spite of there is no verse in the Quran that straight or indirectly places the education of males over women; some Muslims intellectuals are against girl's education by presenting typical argument of the question of chastity and modesty. But the Quran emphasizes modesty is enjoined by both women and men (Quran 24: 30-31) Therefore, it is greatly clear that the Quran demands to procure knowledge by the education of all human beings (both men and women) out of any discrimination or giving priority on one gender over the other. In this regard, Fazlur Rahman states: "The acquisition of knowledge is essential for both men and women, not only to know God with all His Attributes, but also to learn His teaching so that they may find out what the right and proper way of life for them. And this duty falls as much upon women as it does upon men, because they are equally responsible and accountable for their omissions and commissions on the Day of Judgment.” (Rahman, 1980).

\subsection{Knowledge Is a Basis of Islam}

Knowledge is a central foundation of Islam. It has been consistently decided by all Islamic scholars that the first word revealed of the Qur'an was "Iqra" meaning "Proclaim" or "Read" (Ahmed, 2002). In an explanation on verses 96:1-5, Ali states that in Arabic "teach" and "knowledge" have the similar root (Ali, 1989b). The concepts packed in this first revelation establish the close relation between Islam and knowledge. Apart from the name of Allah, knowledge is the next maximum used word in the Qur'an (Ahmed, 2002) and the words that have their source from ilm (know or knowledge) appear 865 times in the Quran (Malaekah, 2000). However, it 
is unfortunate that, in spite of this stress on knowledge in the Quran, many Muslim societies stress is more on Quranic schools with lack of emphasis on education in the physical sciences. The Quran says: "For We (Allah) had certainly sent unto them a Book, based on knowledge, which we explained in detailed-a guide and a mercy for those who believe" (Quran7:52) This indicates that the Quran opinions the acquisition of knowledge is an essential and a right to every Muslim man and woman. From this examination, it can, therefore, be determined that the Quran demands for the education of girls.

\subsection{Compulsory for Real Life}

Islam is that religion which covers all sector of human being. Islam indicates each and every point essential in the life. As a follower of Islam no single action is out of direction of religion. By education individual can identify his status, place in his family, community and his society. He must categorize the relationship between creations and creator applying the Quranic criteria of intelligence, knowledge and virtue (Alam \& Muzahid, 2006). Allah sent human being in the earth to establish right and abolish the wrong. Knowledge is only way to make difference among the right, wrong justice and injustice. The acquisition of knowledge is associated to identify the morals and ethics. It promotes enjoining right and forbidding wrong. Knowledge is pursued and practiced with humility and humbleness and leads to beauty and dignity and justice. Allah said the Holy Quran: "Help ye one another in righteousness and piety, but help ye not one another in sin and rancor: fear Allah: for Allah is strict in punishment.” (Quran 5: 2) This is also girls' right that she must learn the fundamental directions of the shari'ah regarding obey her husband by allowing him his conjugal rights. Islam also commands the Muslim to applied implementation of education: Al Quran commanded the believers to oblige to writing every contract concerning credit. The Holy Quran declares, "O ye who believe! When ye deal with each other, in transactions involving future obligations in a fixed period of time, reduce them to writing Let a scribe write down faithfully as between the parties: let not the scribe refuse to write: as Allah Has taught him, so let him write.” (Quran 2: 282).

\subsection{Acquiring Knowledge Is Part of Worship}

Islam considers seeking knowledge as worship. Girls as good vicegerent of Allah must acquire knowledge as part of worship. The obtaining of knowledge, reading the Quran is worship, traveling to gain knowledge is worship. It was narrated by Abu Hurairah that the Prophet Muhammad (s.m) said, " He who treads the path in search of knowledge, Allah will make that path easy, leading to Paradise for him and those persons who assemble in one of the houses of Allah (mosques), recite the Book of Allah and learn and teach the Quran (among themselves). There will descend upon them tranquility, mercy will cover them, the angels will surround them and Allah will mention them in the presence of those near Him. He who is slow-paced in doing good deeds, his (long) descent does not make him go ahead.” (Muslim, 1971). This Hadith shows significant of knowledge. In another Hadith Abdullah ibn Abbas narrated that Allah's Messenger Muhammad (s.m) said, "Acquiring knowledge in company for an hour in the night is better than spending the whole night in prayer.” (Tirmizi, 1980). From these hadiths denote that all human being obtain the knowledge for performing worship as a servant of Allah.

\subsection{Knowledge for to Be Righteous and Moral}

Islam encourages all the Muslim to striving for acquisition of knowledge. According to the Quran those who fear Allah and are submissive to Him are those who are endued with knowledge. Education generates fear and respect in the heart for Almighty Allah. Allah says, "Only those from amongst His servants who possess knowledge are the ones who fear Allah; surely Allah is Mighty Most Forgiving." (Quran 35: 28). Islam is the simply ethical religion which generates moral values, pious feelings and correct thinking in any one's heart. The aim of Islamic education is to retain Muslim on accurate path. Acquiring the love of Allah is the ultimate goal of human's life. Allah's Messenger said: "If anyone travels on a road in search of knowledge, Allah will cause him to travel on one of the roads of Paradise. The angels will lower their wings in their great pleasure with one who seeks knowledge, the inhabitants of the heavens and the Earth and the fish in the deep waters will ask forgiveness for the learned man.

The superiority of the learned man over the devout is like that of the moon, on the night when it is full, over 
the rest of the stars. The learned are the heirs of the Prophets, and the Prophets leave neither dinar nor dirham, leaving only knowledge, and he who takes it, takes an abundant portion.” (Al-Sijistani \& Hasan, 1993). It was reported by Ibn Abbas that the Messenger of Allah (s.m) said: “A single scholar of religion is more formidable against shaytaan than a thousand devout persons.” (Tirmizi, 1980). The Prophet (s.m) also said about moral importance of Education the Prophet said, "When a man dies, his deeds come to an end, except for three: A continuous charity, knowledge by which people derive benefit, righteous son who prays for him.” (Muslim, 1971, Kitab al wasiyya). Girl has right to possess good, sufficient, appropriate, reasonable and satisfactory religious, good and ethical guidance to sustain for whole lives. She should possess real values, the concept of right and wrong, true and false, correct and incorrect, appropriate and inappropriate and so forth (Afshar, 2013).

\subsection{Protect Oneself and Family from Fire}

Every single Muslim essential believe is the life after death. Belief in hereafter is one of the fundamental objects of faith in Islam. The Quran says: "but it is righteous to believe in Allah and the Last Day” (Quran 2: 177). Al Quran further states: “Lost indeed are they who treat it as a falsehood that they must meet Allah.” (Quran 6: 31). The highest feature of the hereafter life is Allah's Judgment, which will be progressed by allowing the righteous Paradise and the wrongdoers Hell. In this linking the Qur'an again says: "Every soul shall have a taste of death: And only on the Day of Judgment shall you be paid your full recompense.” (Quran 3: 185). “Then those whose balance (of good deeds) is heavy — they will attain Salvation (Paradise): But those whose balance is light, will be those who have lost their souls; in Hell will they abide.” (Quran 23: 102-103) The obligation of human beings is to save themselves and families from Fire. Allah admonishes Muslim to save themselves and their families from Hell. Allah says in the Quran: "O ye who believe! Save yourself and your families from a fire whose fuel is men and stones...” (Quran 66: 6). By examining the above verse, it can be alleged that Allah admonishes Muslims to be moral, righteous and monitor their families to also be righteous by performance what Allah commands and avoiding what He prohibits. This direction can be effective if family members are trained accurately by teaching of the Quran. This guidance must include the fear of Allah; upright lives, it must be for all members of the family (Abukari, 2014). Where the Quran has unambiguously called on believers to save themselves and their families from the Fire, how arise some members of the family are deprived of the modes by which they could be saved from the Fire? Why girl is in some Muslim society denied the right to education?

\section{Prophet Emphasizes on Girls' Education}

Islam was revealed at that time when the Arabs used to infanticide and would regularly bury their girl's babies alive. (Islam, 2105) In the age of ignorance (ayyameJahiliah) born of girl was cause of discredit in the society, Islam absolutely abolishes prohibits this barbaric tendency (Al-Qaradawi, 1985). Islam gradually establishes right of girl in respect of all sectors and ensured honor \& dignity as like male child regardless of gender discrimination. Islam rightly stress to parents on equal treatment of girls' from the shows of love and affection to financial gift as well. Education of girl's is emphasized in many of Al-Hadiths. The Prophet Muhammad (s.m) said: "Seeking knowledge is compulsory for every Muslim" (Al-Bukhari-9). He also said: "Whoever has three daughters, or three sisters, or two daughters, or two sisters and he keeps good company with them and fears Allah regarding them, then Paradise is for him.” (Tirmizi, 1980, Hadith-1916) It was narrated from Aisha “A lady along with her two daughters came to me (Aisha) asking for some alms, but she found nothing with me except one date which I gave to her and she divided it between her two daughters, and did not eat anything herself, and then she got up and went away. Then the Prophet came in and I informed him about this story. He said, "Whoever is put to trial by having to raise daughters and he treats them generously (with benevolence) then these daughters will act as a shield for him from Hell-Fire.” (Al-Bukhari, Hadith-5569). The wives of the Prophet (s.m) took care of the education of the girls'. The Companions took care of the education of their child. For instance, Sa'd b. Abu Waqqas taught her daughter to write.

In addition, He also encouraged for education to the members of the most downgraded communities including slave girls'. This was reported by Abu Musa Al-Ashari that, The Prophet (s.m) said: "He who has a slave -girl and teaches her good manners and improves her education and then manumits and marries her, will get a double reward.” (Majah, 1952). Therefore, girls’ education is similar important matter without view of discrimination among children. The Prophet also creates a new dynamic method for how to be educated. For instance, at the battle of Badr the prophet Muhammad (s.m) gained victory over His foes and seventy enemies were taken to 
prison whose are literate people. In order to benefit from their education the Prophet declared that if one prisoner teaches ten Muslim child how to read and write, this will serve as his ransom and he will be set free. Zayd b. Thabit learned to read and write this way.

\section{Example of Distinguish Woman in the Field of Knowledge}

There is no single verse regarding acquiring knowledge by gender specify. Apart from the reference of Mary (the mother of Jesus) and the wife of Pharoah in the Quran (Quran 66:10-12) as examples of righteous women (which means they had understanding and knowledge). The unique example of two wives of Prophet Muhammad (s.m): Khadijah and Aishah. Khadijah BinteKhuwaylid, the first wife of Prophet Muhammad (s.m), was a rich tradeswoman, the richest woman in Mecca at the time, who exported goods as far away as Syria. To conduct her big business, she employed numerous males and to do so then in Arabia, necessitated that you have a high level of understanding and wisdom. "A" is haSiddiqa, the youngest wife of the prophet (s.m), was very talented and possessed an unbelievable memory. She was a hadith-narrator, scholar, intellectual and jurist of great standing. She has reported 2210 traditions. Abu Hurayra, Abd "Allah b". Amr and Anas b. Malik were the only ones from amongst male hadith-narrators who had narrated more traditions than she did.

There is instance of past women scholars such as zainab al Gazali who was righteous in the real sense of the word (obedient to God) and establish the challenging creativities, ventured into in an attempt to make the truth. In the history of Islam women obtained distinguished positions in the fields of hadith sciences, the science of interpretation, jurisprudence, medical science, poetry and calligraphy. To be submissive to Allah, an individual Muslim requirements some kind of knowledge of what Allah enjoins and what He prohibits. In result, the Quran obviously states that girls have equal right to obtain knowledge or be educated to undertake the status of the righteous people due to their possession of knowledge and understanding that leads to the obedience of Allah in all aspect of life spiritually and practically.

\section{Barriers of Girls' Education in Bangladesh}

Bangladesh is the developing Muslim majority country. The ratio of girls' education gradually increased in the recent decades but this is not satisfactory standard. Several dimensions of barriers are playing vital role to prevent girls' education. The following common barriers to girls' education:

\section{1) Poverty}

In Bangladesh, poverty of family is a prominent factor disturbing girls' education. In case of financial adversity the poor families cannot meet the costs of education e.g. school fees, clothing, shoes and books.

\section{2) Cultural environment}

In the society established belief that girls' are naturally inferior to boys in psychological ability and aptitude, and hence are less worthy of investment for education, is still very pervasive (USAID, 2002). The commonness of child marriage is another hampering factor (Raynor \& Wesson, 2006).

\section{3) Inadequate State strategies and policies}

Inadequate legal outline is absent in the areas e.g. compulsory education, child labor and re-entry into school with deficient national budgetary apportionments to education.

\section{4) School atmosphere}

Schools in Bangladesh offer a miscellaneous atmosphere of learning for girls' depending upon where they are situated, who are involved the management committees are. School atmosphere, for example a separate toilet for girls and potable water is much less favorable in rural areas than in urban areas. Girls' are highly vulnerable outside the home. Parents worried about pregnancy outside marriage, eve teasing and sexual harassment (USAID, 2002).

\section{5) Lack of proper religious knowledge \\ 6) Lack of political will.}

\section{Recommendations}

The following recommendations may be considered for well start of girls' education.

1) Increase the budgetary allocation and actual expenditure to the education sector especially for girls' education.

2) Grow awareness programs with proper direction of religion towards education. 
3) Take particular actions to eradicate Poverty, socio-cultural barriers and horror among girls' and parents both on the way to school and within school.

4) Formulate the policies related to gender education and provide effective mechanism to the proper implementation of Article 17 of Bangladesh constitution.

5) The state apparently prevents the child from leaving school in early. If all child leave schooling for engaged work, then society will suffer irreparable loss in the long run as highly educated and highly skillful people will not be available. This ultimately will lead to the collapse of society (Munir, 2014).

\section{Conclusion}

The first human being has honored for knowledge over all creations and the maiden direction of last religion of Islam is read (Iqra). Education is an organized method through which a child or an adult obtains knowledge, skill experience and sound attitude. It creates an individual civilized, cultured, refined and educated. In Islam the concept of education must take into consideration of all the dimensions consist of tarbiyyah, ta'lìmand ta' $d \bar{\imath} b$. Education of girls not only goes to advance the socioeconomic status as individuals but also increases the general standard of living of society. Islam perfectly emphasizes about acquiring knowledge without gender discrimination between boys and girls for harmonious development of body mind and soul.

\section{References}

Abu Salih, M. Y., \& Nahlawi, A. R. (1982). Dirasatfi'l-tarbiyya al-Islamiyya. Riyad: Muhammad Saud Islamic University.

Abukari, A. (2014). Education of Women in Islam: A Critical Islamic Interpretation of the Quran. Religious Education, 109, 4-23. http://dx.doi.org/10.1080/00344087.2014.868203

Afshar, B. (2013). Islam and Rights of Children. International Research Journal of Applied and Basic Sciences, 7, 750-756.

Ahmed, A. S. (2002). Discovering Islam: Making Sense of Muslim History and Society. London: Routledge.

Ajijola, A. A. (1999). Re-Structuring of Islamic Education. New Delhi: Adam.

Alam, K. U. A., \& Muzahid, M. A. U. (2006). Informal Islamic Education and Its Role in Human Resource Development in Society: A Theoretical Evaluation. IIUC Studies, 3, 83-92.

Alamgeer, P. M. (2010). An Analytical Look into Modern \& Islamic Education. Dhaka: Ahsan Publication.

Al-Attas, M. N. (1978). Islām and secularism. Malaysia: Muslim Youth Movement of Malaysia.

Al-Attas, M. N. (1991). The Concept of Education in Islam a Framework for an Islamic Philosophy of Education. International Institute of Islamic Thought and Civilization, International Islamic University

Al-Attas, N. (1980). The Concept of Education in Islam. Malaysia: Muslim Youth Movement of Malaysia.

Al-Bukhari, M. (1987). Sahih al-Bukhari. Hamdaan Publications.

Al-Ghazali, I. (1993) Ihya’Ulumuddin Juz III. Beirut: Dar ihya al-Kutub al-Ilmiyah, t. th), hlm, 48, 12.

Ali, A. Y. (1989a). The Holy Qur'an: Text, Translation and Commentary. Benton Harbor, MI: Amana Corporation.

Ali, Y. (1989b). Abdullah, the Holy Qur'an: Text, Translation and Commentary. USA: Amana Corporation.

Al-Naquib Al-Attas, S. (1979). Aims and Objectives of Islamic Education. Sevenoaks [etc.]: Hodder and Stoughton [etc.].

Al-Qaradawi, Y. (1985). The Lawful and the Prohibited in Islam. London: Shorouk International.

Al-Sijistani, A. D. u. S. a. A. a., \& Hasan, A. (1993). Sunan Abu Dawud. Lahore: Sh. M. Ashraf.

Ashraf, S. A. (1985). New Horizons in Muslim Education. London: Hodder \& Stoughton.

Ashraf, S., \& Hussain, S. (1979). Crisis in Muslim Education. Jeddah: Hodder and Stoughton.

Asif, M., \& Khan, M. M. (2010). Comparative Study of Analytical and Synthetic Methods of Teaching Mathematics. Journal of International Academic Research, 10, 7.

Badshah, S. N. (2012). Concept of Education in the Light of Quran and Sunnah. International Journal of Education and Social Science, 3, 487.

Daud, W. M. N. W. (1998). The Educational Philosophy and Practice of Syed Muhammad Naquib al-Attas: An Exposition of the Original Concept of Islamization. Kuala Lumpur: International Institute of Islamic Thought and Civilization.

Ibn Sina (1929). Tadabir al-Manazil aw al-Siyasah al-Ahliyyah. Baghdad: Maktba’at al-Falah.

Imaillah, L. (1999). Pathway to Paradise: A Guide of Islam. Carlisle, PA: Ahmadiyya Movement in Islam, Time \& Time Again.

Islam, M. S. (2015). Fundamental Human Rights towards Childhood: Islamic Guidelines Are Unique to Protect the Child. Journal of Alternative Perspective in the Social Sciences, 7, 65-75. 
Khamis, M. H., \& Salleh, M. J. (2010). The Philosophy and Objectives of Education in Islam. Proceedings of the Regional Conference on Islamic Education, Shah Alam, 24-25 July 2010, 1-14.

Khan, M. F. (1988). The Quraanic Principles of Education. Dhaka: Islamic Foundation Bangladesh.

Khan, M. W. (1981). Education and Society in the Muslim World. Jeddah: Hodder and Stoughton.

Majah, I. (1952). Sunan Ibn Majah. Beirut: Darul Kutub Al Ilmiyyah.

Malaekah, M. (2000). What Is the Purpose of Life? Mecca: Islamic Education Foundation.

Munir, M. (2014). Rights of the Child: An Islamic Perspective on Preventing Violence, Abuse, and Exploitation of Children and Pakistani Law. Abuse, and Exploitation of Children and Pakistani Law (December 14, 2014).

Muslim, I. (1971). Sahih Muslim.

Nasr, S. H. (1984). The Islamic Philosophers’ Views on Education. Muslim Education Quarterly, 2, 5-16.

Nik, R., \& Yaacob, N. (2013). An Islamic Perspective on the Role of Education in Responding to Social Issues among Students in Malaysia. Online Submission, 3, 439-446.

Parankimalil, J. (2012). Meaning, Nature and Aims of Education.

https://johnparankimalil.wordpress.com/.../meaning-nature-and-aims-of-

Rahman, F. (1980). Major Themes of the Qur'an. Chicago, IL: Bibliotheca Islamica.

Rayan, S. (2012). Islamic Philosophy of Education. International Journal of Humanities and Social Science, 2, 151-156.

Raynor, J., \& Wesson, K. (2006). The Girls’ Stipend Program in Bangladesh. Journal of Education for International Development, 2, 1-12.

Sarwar, G. (2001). Islāmic Education: Its Meaning, Problems \& Prospects. London: Muslim Educational Trust.

Sharif, M. M. (1964). Islamic and Educational Studies (Volume 2). Lahore: Institute of Islamic Culture.

Tirmizi, A. I. M. a. (1980). Sunan al-Tirmizi. Beirut: Dar al-Fikr.

USAID (2002). https://www.usaid.gov/.

Wan Daud, M. (2010). Al-Attas' concept of ta'dib as true and comprehensive education in Islam'.

Wehr, H., \& Cowan, J. M. (1979). A Dictionary of Modern Written Arabic:(Arab.-Engl.). Otto: Harrassowitz Verlag.

WORLD-COME (1977). Paper Presented at the First World Conference on Muslim Education, Mecca.

Yalgin, M. (1986). Al-jawanib al-asasiyyafi'l-tarbiyyaaI-Islamiyya. Beirut: Mu'assassat al-Rayhani.

Yasin, F., Firdaus, R., \& Jani, M. (2013). Islamic Education: The Philosophy, Aim, and Main Features. International Journal of Education and Research, 1, 1-18. 